\title{
The Effect of Lifestyle and Product Quality on Mobile Phone Purchasing Decisions at Sam Ratulangi University Students in Manado Indonesia
}

\author{
Johana Ratag, Roslina H.S.D. Limpeleh, Anneke M. Kaunang \\ Department Of Accounting, Polytechnic of Manado Country \\ Jufrina Mandulangi \\ Department of Business Administration, Polytechnic of Manado Country \\ DOI: $10.31364 /$ SCIRJ/v6.i12.2018.P1218593 \\ http://dx.doi.org/10.31364/SCIRJ/v6.i12.2018.P1218593
}

\begin{abstract}
The purpose of this research was to determine the effect of lifestyle and product quality on mobile phone purchasing decisions at Samratulangi University Manado Students. The research of associative research is research to find out the relationship between two variables or more. This research examines the influence and relationship between independent variables, namely lifestyle (X1) and product quality (X2) on the dependent variable, namely the purchasing decision (Y). The population in this research were active college students which numbered 2,369 with the number of samples used by 96 respondents. The results of the study show that lifestyle, and product quality simultaneously influence the purchasing decisions of mobile phones. This influence in terms of the coefficient of determination is around 30\%, while the rest is caused by other factors, such as advertising, prices, marketing strategies, customer loyalty, brand image and others. Lifestyle influences purchasing decisions, so that to support lifestyle, mobile purchasing decisions will increase. Product quality has an effect on purchasing decisions, so that by producing a good product it will greatly influence the purchasing decisions of mobile phones.
\end{abstract}

Keywords: Lifestyle, Product Quality and Purchasing Decision

\section{Introduction}

In the current technological era, communication is very important for every human being because without communication, humans cannot interact with others, the world of information technology is indeed always interesting to observe, especially those related to telecommunications. Besides that, communication is needed as a process of socialization in launching the communication process, of course there is a need for an intermediary to communicate. The intermediary can be something that is man-made like a cellphone. Mobile phone is a wireless voice communication tool that can go everywhere and is very easy for humans to socialize. Previously mobile phone buyers only bought based on their use as a communication tool but now with many brands of cellphones marketed offering attractive features, and sophisticated models so that buyers have ruled out their main uses as communication tools consumers are now leads to lifestyle and product quality. The students also, do not want to be outdated, especially in the case of cell phone use. In connection with the various thoughts above, and based on the experience of the researchers while associating with Sam Ratulangi University students, they were very concerned about lifestyle, and the quality of mobile phones when making mobile purchasing decisions. This can be seen, when mobile phones are used as a communication tool, which is commonly used by most students. From the description above, the authors are interested in knowing more about the Effect of Lifestyle and Product Quality on Mobile Purchase Decisions on Students of the Sam Ratulangi University in Manado Indonesia.

\section{Research Methods}

The type of research used is associative. According to Sugiyono (2006) associative research is research that aims to determine the relationship between two or more variables. This study examines the effect and relationship between independent variables, namely lifestyle (X1) and product quality (X2) on the dependent variable, namely the purchasing decision (Y). The population in this study were active students who were 2,369 students. The author uses the sample determination formula as suggested by the Slovin formula:

$\mathrm{n} \quad=\frac{N}{N(e 2)+1}$ 
Where :

$1=$ constant, $\mathrm{n}=$ sample size, $\mathrm{N}=$ population size, $\mathrm{e}=$ percent allowance for inaccuracy because sampling errors can still be tolerated $(10 \%)$.

Jadi $: \mathrm{n}=\frac{2369}{2369(0.01)+1}=\frac{2369}{24.69}=95.9498($ dibulatkan 96 responden $)$

The data used in this research are: literature research, data collection, from various literature and scientific works related to the problems encountered in preparing this paper. Field research, carried out by: Observation, conducting observations directly to the research site on the research problem. Interview, data collection is done by asking directly to the user who made the respondent. Questionnaires, data carried out by giving a set of questions, or written statements to students using mobile phones. This study will use two main variables, namely the independent variable and the dependent variable. For independent variables consists of two variables, namely lifestyle (X1) and product quality (X2), and one dependent variable is the purchase decision (Y1). The scale used in this study is the Likert scale, which according to Sugiyono (2010), the Likert scale, the variables to be measured are described as indicators of variables. Then, the indicator is used as a starting point for compiling instrument items, which can be in the form of statements and questions. In this case a five-level scale (Likert) is used which consists of five answer choices, namely: SA (Strongly Agree), A (Agree), LA (Less Agree), D (Disagree), SD (Strongly Disagree). With the assessment of the score as follows: Strongly agree: 5, Agree: 4, Less agree: 3, Disagree: 2 and Strongly disagree: 1. To find out the relationship between independent variables (x), and variables $(\mathrm{Y})$, calculations are made using the method of multiple linear regression analysis. The equation model used in this research, as follows: According to Hussein (2008) the formulation of multiple linear regression is:

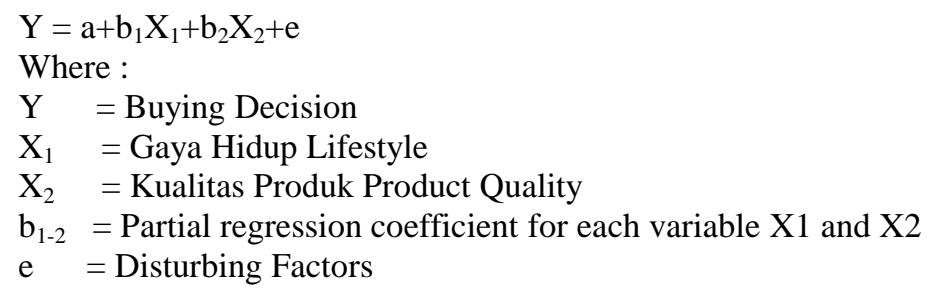

III. Discussion

3.1 Respondents General Description

Table 3.1 Number of Respondents by Gender

\begin{tabular}{|c|c|c|}
\hline Gender & Number & Precentage (\%) \\
\hline Man & 42 & 43,75 \\
\hline Woman & 54 & 56,25 \\
\hline Number & $\mathbf{9 6}$ & $\mathbf{1 0 0}$ \\
\hline
\end{tabular}

Data source : Primary data

Table 3.2 Number of Respondents by Age

\begin{tabular}{|c|c|c|}
\hline Age & Number of Respondents & Precentage (\%) \\
\hline $19-21$ & 20 & 56,25 \\
\hline $21-23$ & 54 & 22,91 \\
\hline $23-25$ & 22 & \\
\hline
\end{tabular}




\begin{tabular}{|c|c|c|}
\hline Number & 96 & 100 \\
\hline
\end{tabular}

Data source : Primary data

Table 3.3 Number of Respondents by Year of Entry

\begin{tabular}{|c|c|c|}
\hline Year of Entry & Number of Respondents & Precentage (\%) \\
\hline 2018 & 7 & 7,29 \\
\hline 2017 & 10 & 10,41 \\
\hline 2016 & 25 & 22,91 \\
\hline 2015 & 45 & 46,87 \\
\hline 2014 & 9 & 12,5 \\
\hline Number & $\mathbf{9 6}$ & $\mathbf{1 0 0}$ \\
\hline
\end{tabular}

Data source : Primary data

\subsection{Research Analysis}

The steps taken in this test, namely by entering variable data into the Microsoft Excel program. After the summary of the tabulation results data is entered into the Microsoft Excel program. Then, it is transferred to the Data View section in the SPSS Version 17.0 Software Program, for data processing which is then analyzed further.

\subsubsection{Validity Testing}

As previously explained, testing the validity, the results of the validity test with a significant level of 5\%, with the number of respondents as many as 30 people obtained critical numbers from the $\mathrm{r}$ table (table $\mathrm{r}$ product moment) obtained was 0.361 . Furthermore, using the help of SPSS version 19 software, the results obtained as found in the following table.

Table 3.4 Results of Variable Lifestyle Validity Test (X1)

\section{Item-Total Statistics}

\begin{tabular}{|c|c|c|c|}
\hline & Value r Table & Corrected Item-Total Correlation & Information \\
\hline x1.1 & 0,361 & $\mathbf{. 5 3 0}$ & Valid \\
x1.2 & 0,361 & $\mathbf{. 7 2 5}$ & Valid \\
x1.3 & 0,361 & $\mathbf{. 6 8 2}$ & Valid \\
\hline
\end{tabular}

Table 3.4 X1.1 shows the Pearson correlation value of 0.530, X1.2, showing the Pearson correlation value of 0.725, X1.3, showing the Pearson correlation value of 0.682. Thus, all items are valid, because the value of Pearson Correlation (X1) is greater than 0.361 . $\mathrm{X} 1$ data is valid.

Table 3.5 Test for Product Quality Validity (X2)

\section{Item-Total Statistics}

\begin{tabular}{|l|l|l|l|}
\hline & Value r Table & Corrected Item-Total Correlation & Information \\
\hline
\end{tabular}




\begin{tabular}{|c|c|c|c|}
\hline x2.1 & 0,361 & $\mathbf{. 5 5 1}$ & Valid \\
$\mathrm{x} 2.2$ & 0,361 & $\mathbf{. 6 6 4}$ & Valid \\
$\mathrm{x} 2.3$ & 0,361 & $\mathbf{. 6 3 9}$ & Valid \\
$\mathrm{x} 2.4$ & 0,361 & $\mathbf{. 5 7 7}$ & Valid \\
\hline
\end{tabular}

Table 3.5 above X2.1 shows pearson correlation value of $0.551, \mathrm{X} 2.2$ shows pearson correlation value of 0.664 , X2.3 shows pearson correlation value of $0.639, \mathrm{X} 2.4$ shows pearson correlation value of 0,557 . Thus, all items are valid, because the Pearson Correlation (X2) value is greater than $0.361 . \mathrm{X} 2$ data is valid.

Table 3.6 Validity Test Results of Variables Purchase Decisions (Y)

Item-Total Statistics

\begin{tabular}{|c|c|c|c|}
\hline & Value r Table & Corrected Item-Total Correlation & Information \\
\hline y1 & 0,361 & $\mathbf{. 5 7 3}$ & Valid \\
y2 & 0,361 & $\mathbf{. 4 5}$ & Valid \\
y3 & 0,361 & $\mathbf{. 6 7 0}$ & Valid \\
y4 & 0,361 & $\mathbf{. 6 2 4}$ & Valid \\
y5 & 0,361 & $\mathbf{. 6 4 8}$ & Valid \\
\hline
\end{tabular}

Table 3.6 above Y1 shows pearson correlation value of 0.573 , Y2 shows pearson correlation value of 0.455 , Y3 shows pearson correlation value of 0.670 , Y4 shows pearson correlation value of 0,624 , Y5 shows pearson correlation value of 0.648 . Thus all items are valid, because the value of Pearson Correlation (X2) is greater than 0.361. Y data is valid.

\subsubsection{Reliability Testing.}

Reliability testing method is to use Reliability analysis through the Cronbach Alpha method which is measured based on alpha scale 0 to 1 . Measures of alpha stability can be interpreted as in Table 3.7 below.

Table 3.7

Level of Reliability Based on Alpha Value

\begin{tabular}{|c|c|}
\hline Alpha & Level of Reliability \\
\hline $0,00 \mathrm{~s} / \mathrm{d} 0,20$ & Less reliable \\
$>0,20 \mathrm{~s} / \mathrm{d} 0,40$ & Somewhat reliable \\
$>0,40 \mathrm{~s} / \mathrm{d} 0,60$ & Pretty reliable \\
$>0,60 \mathrm{~s} / \mathrm{d} 0,80$ & Reliable \\
$>0,80 \mathrm{~s} / \mathrm{d} 1,00$ & Very reliable \\
\hline
\end{tabular}

Source : Triton P.B (2006) 
After the data is processed using the help of SPSS Version 19.0 Software to test the level of reliability, the resulting output can be seen in Table 3.8 below.

Table 3.8 Variable X1

\section{Reliability Statistics}

\begin{tabular}{|c|c|}
\hline Cronbach's Alpha & N of Items \\
\hline .798 & 3 \\
\hline
\end{tabular}

Testing the level of reliability, as presented in table 3.8, then in the Reliability statistics section there is cronbach's alpha $=0.798$ with $\mathrm{N}$ of items, or question items as many as 3 questions. So, the Cronbach alpha value of output $=0.668$ lies between 0.60 to 0.80 so the level of reliability is reliable

\section{Table 3.9 Variable X2}

\section{Reliability Statistics}

\begin{tabular}{|c|c|}
\hline Cronbach's Alpha & N of Items \\
\hline .807 & 4 \\
\hline
\end{tabular}

From testing the level of reliability as presented in table 3.9, then in the Reliability statistics section there is cronbach's alpha $=0.807$ with $\mathrm{N}$ of items, or question items as many as 4 questions. So, the Cronbach alpha output value $=0.807$ is located between 0.80 to 1 so that the reliability level is very reliable.

Tabel 3.10 Variabel Y

\section{Reliability Statistics}

\begin{tabular}{|c|c|}
\hline Cronbach's Alpha & N of Items \\
\hline .740 & 5 \\
\hline
\end{tabular}

From testing the level of reliability as presented in table 3.10 , then in the Reliability statistics section there is cronbach's alpha $=0.740$ with $\mathrm{N}$ of items or question items as many as 5 questions. So, the Cronbach alpha value of output $=0.740$ is located between 0.60 to 0.80 so the reliability level is reliable.

\subsubsection{Classic assumption test}

\subsubsection{Test for Normality}

The purpose of the normality assumption test is to test whether in a regression model, the independent variable and the dependent variable have a normal distribution or not. A good regression model is normal, or near normal data distribution. The basis of decision making is if the data spreads around the diagonal line, and follows the direction of the diagonal line, then it meets the requirements for the assumption of normality. Based on the results of calculations using the SPSS Version 17.0 Program, as can be seen in Picture 3.1 .

Picture 3.1 


\section{Normal P-P Plot of Regression Standardized Residual}

\section{Dependent Variable: Keputusam Pembelian}

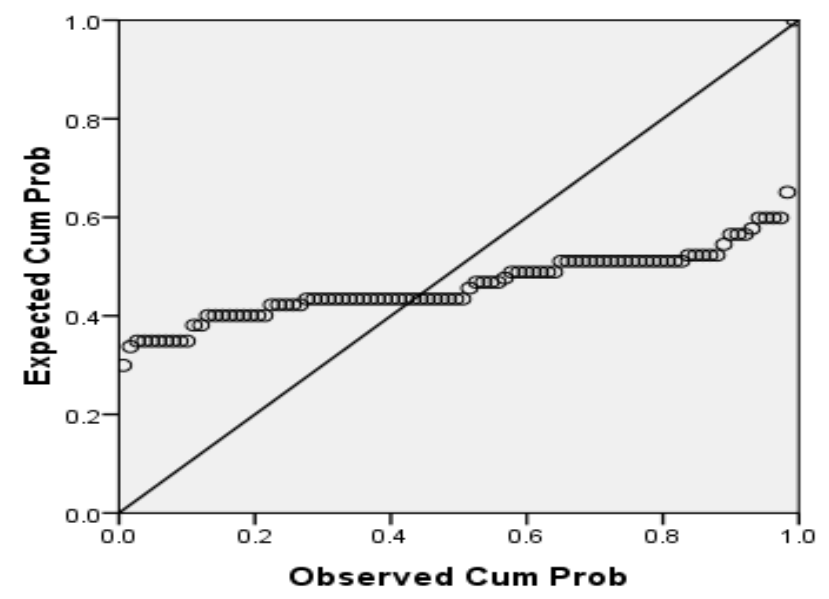

\subsubsection{Autocorrelation Test}

A good regression equation is that does not have an autocorrelation problem, if there is an autocorrelation then the equation is not good / not suitable to use the prediction. To determine whether or not the problem of autocorrelation with the Durbin-Watson test is as follows:

Table 3.11

\section{Model Summary ${ }^{\mathrm{b}}$}

\begin{tabular}{|l|c|c|c|c|c|}
\hline \multirow{2}{*}{ Model } & $\mathrm{R}$ & $\mathrm{R}$ Square & Adjusted R Square & Std. Error of the Estimate & Durbin-Watson \\
\hline 1 & $.548^{\mathrm{a}}$ & .300 & .221 & 5.18773 & $\mathbf{1 . 1 0 6}$ \\
\hline
\end{tabular}

a. Predictors: (Constant), Product Quality, Lifestyle

b. Dependent Variable: Buying decision

From the results above, the $\mathrm{d}$ value generated from the regression model is 1.106 . The $\mathrm{D}-\mathrm{W}$ number of 1.106 is between -2 to +2 , thus it can be concluded that the regression model has no autocorrelation.

\subsubsection{Multicollinearity Test}

Tabel 3.12 


\section{Coefficients $^{\mathrm{a}}$}

\begin{tabular}{|l|l|c|c|}
\hline \multicolumn{2}{|c|}{ Model } & \multicolumn{2}{c|}{ Collinearity Statistics } \\
\cline { 3 - 4 } \multicolumn{2}{|c|}{} & Tolerance & VIF \\
\hline \multirow{3}{*}{1} & (Constant) & & 1.095 \\
\cline { 2 - 4 } & $\mathrm{X} 1$ & .914 & 1.095 \\
\cline { 2 - 4 } & $\mathrm{X} 2$ & .914 & \\
\hline
\end{tabular}

VIF value in table 3.12, each independent variable under the value of 5, namely lifestyle (X1) of 1.095, product quality (X2) of 1.095, it can be concluded that between the research variables are free of multicollinearity.

\subsubsection{Uji Heteroskedastisitas}

To detect the presence or absence of heteroscedasticity, it can be done by looking at the presence or absence of a particular pattern on the Scatter Plot chart. (1) If the Scatter Plot chart does not form, or describes a particular pattern, it means that the regression model can be free from heteroscedasticity. (2) If there is no clear pattern of points spreading above, and below number 0 on the $\mathrm{Y}$ axis, heteroscedacity does not occur. Based on the results of calculations using the SPSS Version 17 Program, the Scatterplot Chart can be seen in Fiture 3.2.

\section{Picture 3.2 Heteroscedasticity Test}

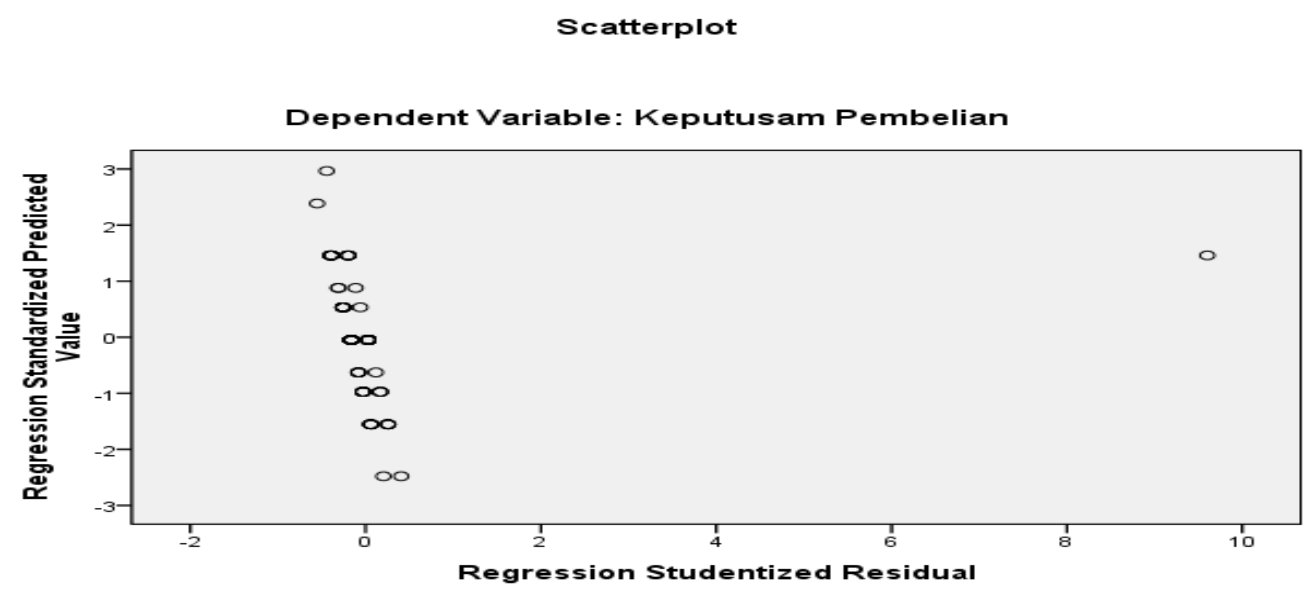

\subsubsection{Multiple Linear Regression Analysis}

Based on the results of calculations using SPSS version 17.00 software as shown in the appendix, it can be seen in Table 3.12 Coefficientsa that the regression models obtained are:

$$
\begin{aligned}
& Y=\alpha+\beta_{1} X_{1}+\beta_{2} X_{2}+e \\
& Y=6.642+0.712 X_{1}+0.157 X_{2}
\end{aligned}
$$

With interpretation, the constant $\alpha$ of 6.642 gives an understanding that if Lifestyle (X1), Product Quality (X2) equals zero (0), then the amount of Purchase Decision is 6.642 units of score. The regression coefficient (X1) of 0.712 shows that if the lifestyle variable increases by $1 \%$, then the purchasing decision variable $(\mathrm{Y})$ will increase by $0.712 \%$, assuming the other variables are considered constant. The regression coefficient (X2) of 0.157 shows that if the product quality variable has increased by $1 \%$, then the purchasing decision variable $(\mathrm{Y})$ will increase by $0.157 \%$ assuming the other variables are considered constant.

\subsubsection{Correlation Coefficient and Determination}

It can be seen that the linear correlation coefficients produced between the variables of Lifestyle (X1), product quality (X2), and purchasing decisions $(\mathrm{Y})$ are 0.548 . The value of correlation $(\mathrm{R})$ of 0.531 indicates that there is a moderate / sufficient relationship between variables X1, X2, and X3 with variable $\mathrm{Y}$. While the value of $\mathrm{R}$ Square, or the coefficient of determination of 
300 indicates that the contribution of variables X1 and X2 to explain the Y variable model that the independent variable can explain the dependent variable model by $30 \%$, and the remainder is explained by other variables not included in this research.

\subsubsection{F test and $t$ test}

Table 3.13

\section{ANOVA ${ }^{b}$}

\begin{tabular}{|rr|r|r|r|r|r|}
\hline Model & & Sum of Squares & Df & Mean Square & F & Sig. \\
\hline 1 & Regression & 56.093 & 2 & 28.046 & 11.042 & $.047^{\mathrm{a}}$ \\
& & 2502.865 & 93 & 26.913 & & \\
& & & & & & \\
& Residual & 2558.958 & 95 & & & \\
\end{tabular}

a. Predictors: (Constant), Product Quality, Lifestyle

b. Dependent Variable: Buying decision

From the table above, it can be seen the results of Fcount $=11,042$ and Ftable with a confidence level of 95\% where df 1 (3-1) and df 2 (30-3-1) are equal to 3.37 with a significant result of 0.047. So it can be seen that Fcount> Ftable can be concluded that Ho is rejected and $\mathrm{Ha}$ is accepted. Furthermore, it can be seen at a significant $0.047<0.05$, it can be stated that Simultaneously, the Lifestyle and Product Quality variables significantly influence the Purchasing Decision.

Table 3.14

\begin{tabular}{|c|c|c|c|c|c|}
\hline \multirow[b]{2}{*}{ Model } & \multicolumn{2}{|c|}{ Unstandardized Coefficients } & \multirow{2}{*}{$\begin{array}{c}\begin{array}{c}\text { Standardized } \\
\text { Coefficients }\end{array} \\
\text { Beta }\end{array}$} & \multirow[b]{2}{*}{$\mathrm{t}$} & \multirow[b]{2}{*}{ Sig. } \\
\hline & $\mathrm{B}$ & Std. Error & & & \\
\hline $1 \quad$ (Constant) & 6.642 & 4.269 & & 1.556 & .123 \\
\hline Lifestyle & .712 & 1.004 & .076 & .709 & .040 \\
\hline Product quality & .157 & .821 & .151 & 1.410 & .006 \\
\hline
\end{tabular}

a. Dependent Variable: Buying Decision

Testing the hypothesis to determine the effect of each independent variable (X) on the dependent variable (Y) partially by using the $t$ test using the criteria, which can be seen at a significant level $<0.05, \mathrm{H}_{0}$ is rejected, and $\mathrm{H}_{\mathrm{a}}$ is accepted. Based on the statistical value on the results of multiple linear regression analysis, it can be seen that the significance value of the lifestyle variable (X1) 0.040

Model Summary

\begin{tabular}{|r|r|r|r|r|r|}
\hline & & & & \\
Model & $\mathrm{R}$ & $\mathrm{R}$ Square & $\begin{array}{c}\text { Adjusted R } \\
\text { Square }\end{array}$ & Std. Error of the Estimate & Durbin-Watson \\
\hline 1 & $.548^{\mathrm{a}}$ & .300 & .221 & 5.18773 & 1.106 \\
\hline
\end{tabular}

a. Predictors: (Constant), Product Quality, Lifestyle
$<0.05$,

it can be conclu ded that $\mathrm{H}_{0}$ rejecte $\mathrm{d}$, and $\mathrm{H}_{\mathrm{a}}$ is accept 
ed. Statistical results on multiple linear regression analysis, it can be seen that $t_{\text {count }}$ of product quality variables (X2) obtained the significance value of the independence variable (X2) 0.006>0.05, it can be concluded that $\mathrm{H}_{0}$ is accepted, and $\mathrm{H}_{\mathrm{a}}$ is rejected.

\subsubsection{Influence Analysis}

\subsubsection{Effect of Lifestyle on purchasing decisions}

The first hypothesis of statistical testing shows the significance value of the product quality variable $=0.040<0.05$, then it can be stated that Ho is rejected and Ha is accepted. partially (variable X1) product quality influences purchasing decisions (variable Y). The results of testing hypothesis 1 found that lifestyle has an influence on student decisions in buying mobile phones. Lifestyle reflects the values embraced by the community itself. Because consumers generally not only choose a product because of its function, but also a sense of pride, and recognition of owning the product, because in addition to seeing its function they also see other factors in making a purchase. For example, current trends and to support appearance even to improve his lifestyle. So, the higher the lifestyle in this case students, the higher the purchasing decision for the handphone.

\subsubsection{Effect of product quality on purchasing decisions}

Statistical results on multiple linear regression analysis, it can be seen that product quality (X2) obtained a significance value of $0.006>0.05$, it can be stated that Ho is rejected and Ha is accepted. Thus, product quality (variable X2) influences purchasing decisions. These results are in line with those conducted by America Society Quality Control, Kolarik (1995) cited by Setiadi (2008). Explain that quality influences purchasing, they conclude that purchasing decisions are influenced by quality, performance, durability, and convenience to be used, which are very decisive factors in purchasing decisions. Whereas according to Kotler and Armstrong (2008) by producing a good product will be very influential on consumer purchasing decisions. These results explain that the results of consumer experience in using the product will produce a consumer assessment of the product. If the product can satisfy the desires of consumers, consumers will give a positive assessment of the product. With this assessment, consumers will still want to buy the product. This result explains that in general consumers in spending their money will take into account the quality that can be obtained from the money they will spend. Thus, consumers will consider product quality as an exchange, sacrifice money used by consumers, to buy a product including the type of handphone. Empirical data from this study shows that mobile phones are valued by consumers having the ability to maintain the quality of their products. From these conditions further, there is an increasingly large purchasing decision that consumers can make.

\section{Conclusion}

This research aims to determine the effect of lifestyle and product quality on mobile phones purchasing decisions, case studies on students of Sam Ratulangi University, Manado. Based on the results of the study it can be concluded as follows.

1. Lifestyle and Product Quality simultaneously effect the decision to purchase mobile phones. And this effect in terms of the coefficient of determination is around 30\% while the rest is caused by other factors. Such as advertising, prices, marketing strategies, customer loyalty, brand image and others.

2. Lifestyle influences the Purchasing Decision, so as to support the lifestyle, the decision to purchase mobile phones will increase

3. Product quality has an effect on purchasing decisions, so that by producing a good product will greatly effect the purchasing decision of the mobile phones

\section{Referensi}

Arikunto, S. 2006. Research Procedure A Practice Approach. Revised Edition. Rineka Cipta. Jakarta.

Howard. 2005. Quality Management, Graw Hill. MC. Singapura.

Husein, Umar. 2008. Research Methods for Thesis and Business Thesis, Second Edition. PT Raja Grafindo Persada. Jakarta.

Hasan, Iqbal. 2003. Statistics, second edition. Bumi Aksara. Jakarta

Kotler, P. and Armstrong, G. 2008. Principles of Marketing.Issue 12 . Erlangga. Jakarta.

Schiffman, L. and Kanuk, L. 2006. Consumer Behavior, Issue 7 . PT. Indeks. Jakarta.

Setiadi, N, J. 2008. Consumer Behavior, Contemporary Perspective on Motives and Objectives of Consumer Desires.. Pranata Media Group. Jakarta. 
Simamora, Henry. 2004. Marketing Management. Volume 2. Salemba Empat. Jakarta..

Sunarto. 2006. Consumer Behavior, Amus Publisher. Yogyakarta.

Sugiyono. 2006. Administrative Research Methods, Print 14. CV. Publisher. Bandung.

Sugiyono. 2010. Business Research Methods (Quantitative, Qualitative Approaches and R \& D), Alfabeta Publishers. Bandung.

Tjiptono, F. 2005. Total Quality Service, Andi Publisher. Yogyakarta.

Tjiptono, F. 2008. Strategic Marketing, Andi Publisher. Yogyakarta.

Triton P.B. 2006. SPSS Version 13.1 Applied Parametric Statistics Research, Andi Publisher Yogyakarta:

Vincent, Gasperz. 2003. Total Quality Manajemen. Gramedia Pustaka utama. Jakarta.

Nilowardhono, S. 2007. Identification and Analysis of Factors Affecting Consumers in Buying Nokia Mobile Phones (Case Study: Surabaya Consumers). 